\title{
Reading Black Bloc Aesthetically
}

\author{
Claryn Spies ${ }^{1}$
}

While black bloc has been persistently misunderstood and maligned by the mainstream media and leftist intellectuals alike, rereading this tactic as an aesthetic practice opens new and more interesting methods of appraisal. This paper considers three ways of reading black bloc: first, how participation in a black bloc can be an ontologically transformative experience for its participants; second, how property destruction associated with black blocs can have transformative effects on its spectators; and third, how black bloc is particularly well-suited to what Jacques Rancière calls the redistribution of the sensible. These accounts provide alternative lenses through which black bloc can be brought into focus, and suggest that the bloc's lack of concrete demands or fixed membership, its fleeting temporality, and its refusal to either identify itself with a particular party or class, or to engage with "politics as usual" - the very things that frustrate its critics - can be read as its greatest strengths. In entertaining a multiplicity of ways of seeing black blocs, we may loosen ourselves from the prevailing criticisms that eschew nontraditional forms of demonstrations, and shift the horizon of what we find to be politically possible. [Article copies available for a fee from The Transformative Studies Institute.E-mail address: journal@transformativestudies.org Website: http://www:transformativestudies.org (C2021 by The Transformative Studies Institute. All rights reserved.]

KEYWORDS: Aesthetics, Direct Action, Anonymity, Subjectivity, Jacques Rancière.

\footnotetext{
${ }^{1}$ Claryn Spies holds a B.A. in Political Studies and Philosophy from Bard College and an M.A. from Binghamton University's Program in Social, Political, Ethical and Legal Philosophy, and is currently a Ph.D. student in Philosophy at Villanova University in Philadelphia. Address correspondence to: Claryn Spies, Villanova University, SAC 108, 800 Lancaster Avenue, Villanova, PA 19085; e-mail: cspies@villanova.edu.
} 